\title{
The Politics and Challenge of Institutional Transformation in Sub-Saharan Africa
}

\author{
Michael W. Kpessa \\ Institute of African Studies, \\ University of Ghana, Legon \\ Accra, Ghana \\ DOI: http://dx.doi.org/10.4314/gjds.v9i2.1
}

\begin{abstract}
This paper draws insights from theories of institutional change to analyze the interface between indigenous and contemporary socio-political institutions of governance in Sub-Saharan Africa. It shows that, although critical junctures are assumed to be path-departing moments, they can result in fundamental divisions in overall institutional structures by grafting new institutions onto existing ones while at the same time re-enforcing the reproduction of existing institutional logics. Tracing the politics of institutional development and change in SSA over time, the paper shows that colonial rule left an unintended legacy of institutional dualism-the formal and the informal - which the recent processes of structural adjustment and democratizations have reenforced. Thus, the development of governance institutions in SSA is far from over as actors and interests associated with both formal and informal institutional settings compete for legitimacy and sovereignty, while at the same time introducing new goals to enhance their efficiencies, and combining existing elements within the overall institutional repertoire in a process of change within and beyond path dependence.
\end{abstract}

KEY WORDS: Governance, Socio-Political Institutions, Institutional Transformation, Political Theories

\section{Introduction}

How do socio-economic and political transformations in Sub-Saharan Africa (SSA) contribute to our understanding of institutional development and change? Until recent, works by Thelen, (2003), Hacker (2004), Campbell (2004), Beland (2007) and Weyland (2008) that provide some insightful models for mapping and explaining institutional change, institutionalist analyses had, for a long time, focused on institutional stability (Mahoney 2000, 2006; Pierson 1996, 1998, 2000, 2004) and generally neglected the processes of change (Clemens and Cook 1999). Yet, because much of the contemporary models for analyzing institutional change draw exclusively on evidence from advanced 
industrialized countries to back their analyses, "empirical evidence backing these models" are not only limited, "there is ample room for empirical studies that could provide more ground to (or challenge) these models" (Beland 2007: 20). In other words, the extent to which the mechanisms for explaining institutional change can travel beyond the shores of the advanced industrialized societies remains largely unknown. This paper draws on institutionalist debates about change and stability to analyze the processes of economic and political transformations in SSA. Taking colonialism, structural adjustment, and democratization as critical moments that foster the introduction of path-departing changes, the paper shows that critical junctures can also undermine path-departing initiatives and thus, become catalysts for activating and empowering already existing institutions.

The paper demonstrates that the question of institutional change is more complex than a simple two-sided debate between path-dependence and path-departure, or continuity and change. This analysis is done through a discussion of the legacies of colonial rule, economic reforms and democratization, and the resultant resurgence of traditional political institutions in SSA countries. First, the paper suggests that colonialism altered the configuration of political institutions in SSA by 'grafting' new institutions into an "otherwise stable institutional framework" (Thelen 2004: 35). However, this did not stop the overall endogenous development of indigenous political institutions. Second, although structural adjustment and democratization programs were introduced to reinforce the stability and continuity of the institutional frameworks grafted during the colonial era, they have produced unintended consequences of resuscitating African traditional political institutions as well as peoples' faith in them in ways that challenge the autonomy and legitimacy of the postcolonial state. While this has provided indigenous political institutions and the actors associated with them windows of opportunity (Kingdon 1995), to reconfigure their institutional goal through "conversion" (Beland 2007; Hacker 2004; Thelen 2003); actors associated with the institutions of the post-colonial state (politicians and policy makers) have also resorted to "bricolage" (Campbell 2004) as a strategy to transform the overall institutions of governance in SSA countries.

The rest of the paper is organized into five sections; the first section discusses contemporary perspectives on institutional stability and change by focusing on path dependence, critical junctures, layering, conversion and bricolage. The second section provides an institutional analysis of early political institutions in SSA prior to the introduction of modern political institutions of governance in the colonial era. The purpose of this section is to elucidate the historical and institutional legacies that developed out of the interactions between indigenous and colonial institutional arrangements; and their subsequent impact on politics in SSA countries, which is the focus of the analyses in section three. Section four shows how socio-economic reforms and democratizations as institutional reforms aimed at reconfiguring incentive structures of actors, challenge the legitimacy and relevance of the African state by enhancing the opportunity structures of traditional political institutions to operate in parallel with the institutions of the post-colonial state. The final section underlines the theoretical 
contribution of the paper by situating the empirical discussions in the broader theoretical debates on institutional change.

\section{Institutional Stability And Change}

Comparative political scientists have been debating the dynamics of institutional evolution, stability and change in more recent times than ever before. This interest has been generated by criticisms that institutionalist theories are fixated on institutional continuity and stability to the extent that they have become insensitive to the analysis of change. Broadly, there are two schools of thought driving the debate. The first school is represented by scholars like Pierson (1994, 1996, 1998, 2000, 2004) and Mahoney (2001, 2000, 2006) who argue that once institutions are well established, they become difficult to change without exogenous pressures. Using insights from path-dependence defined as "historical sequences in which contingent events set into motion institutional patterns or event chains that have deterministic properties" (Mahoney 2000: 507) to describe institutional development, these scholars argue that, over time, institutional arrangements typically become more difficult to change; and previously obtainable options become difficult to select no matter how efficient they are deemed to be for solving present problems.

Path-dependence analysts argue that institutions have large set-up costs and once a particular institution is established, actors learn to become familiar with its operations and develop resistance for its transformation. In addition, institutions are not only usually established in ways that make them difficult to change, but also beneficiaries of existing institutional arrangements organize to promote their interest thereby reinforcing the persistence of such institutions (Pierson 2000, 1993, 1996, 1998, 2000, 2004). Criticized for being overly deterministic and fixated on explaining institutional persistence, scholars who belong to this school of thought point to critical junctures, defined as rare historical moments, that feature crises, external shocks or major historical events with capacities to disrupt existing patterns of institutional development and introducing fundamental departing initiatives as the main mechanisms of change (Pierson 2000; Mahoney 2000, 2006).

The path-dependence notion of institutional change has been criticized by a second school of thought led by Thelen (2003), Hacker (2004), Campbell (2004) and Beland (2007). This second category argue that while the notion of path-dependence and critical junctures may be suitable for explaining revolutionary or major path-departing changes, they cannot explain incremental, evolutionary and other mechanisms of institutional path-departures. The core argument here is not one of a complete rejection of pathdependent explanations, but a recognition and acknowledgement of other mechanisms of institutional change. As Beland (2007) has noted, institutional transformations do occur through "endogenous mechanisms of change" that "are more influential than exogenous ones" (p. 22). To illustrate this argument, Thelen (2003) has provided two insightful 
mechanisms through which scholars can map out and explain institutional change beyond path-dependence and critical junctures. These are institutional layering and institutional conversion.

Institutional layering refers to the act of grafting or inserting a new institution as a layer on top of or beside an "otherwise stable institutional framework" with the goal of altering the overall trajectory of an existing institution (Thelen 2004: 35). Conversion as a mechanism of institutional change involves the act of incorporating new goals and/or the inclusion of new actors in the operations of an existing institutional arrangement with the purpose of using them to "alter the institutional role or the core objectives" of that institution (Beland 2007: 22). These concepts which were developed by Thelen (2003) and illustrated further in the works of Beland (2007) and Hacker (2004) differ from, but share similar assumptions about institutional change with Campbell's (2004) idea of bricolage where actors combine existing institutional principles and practices to address new challenges in ways that transform the overall trajectories of existing institutional arrangements.

The debate about stability and change is useful for understanding the complexities involved in the evolution and transformation of socio-political institutions over time. For the most part, however, the theoretical perspectives on critical junctures, layering, conversion and bricolage depict each of these concepts as distinct mechanisms of institutional change. As the ensuing discussions of institutional development and change in SSA suggest, however, critical junctures do not always produce their intended pathdeparting change. Rather, they can set in motion an unintended process of institutional layering in ways that strongly legitimate and re-enforce pre-existing institutions against those introduced at critical junctures. When this happens, it presents windows of opportunity for actors and beneficiaries associated with existing and new institutions to change the dimensions of their institutional frameworks through the processes of conversion and bricolage.

The analyses this far point to the fact that institutional change is much more complex than any of the above mechanisms alone may suggest. The important thing, however, is that these mechanisms of institutional change enable us to map out the "creative processes in which actors make decisions about how to combine the institutional elements at their disposal" (Campbell, 2004: 71), and the extent to which institutions empower or constrain actor ability to foster change. Thus, contrary to the notion that institutionalist theories do not have a place for agency, these mechanisms are infused with the role of actors not only in path-departing initiatives, but also in path-dependent evolutionary processes.

\section{Institutional Analysis of Early Political Systems in SSA}

The study of institutional change demands a thorough understanding of the institutional contexts within which the analyses are situated. Until recently it was assumed that SSA 
countries had no institutions of governance prior to the colonial era. Now, historical, sociological and anthropological studies have provided ample evidence to support the argument that pre-colonial African societies had effective institutions of governance long before their encounters with Arabian and European traders and explorers (Busia, 1951; Buur \& Kyed 2005, 2007; Khapoya, 1994; Naudascher \& Kgatlhanye, 1997; Ubink, 2008). Pre-colonial socio-economic and political institutional rules are said to have revolved around traditional leaders often described by various appellations in their societies but collectively known as chiefs. The term traditional leader is used to include any individual or aristocrat chosen by his/her societies to be king or queen, in the sense of holding socioeconomic and political office, as well as presiding over religious and customary ceremonies (Ray, 1998; Ray \& Reddy 2003).

Baynes (1993) argues that political legitimacy is an essential element that explains why the modern state is able to force compliance within well-defined laws. In pre-colonial Africa, traditional leaders derived their political authority and legitimacy from time honored institutional rules and norms that pertained to how such leaders were chosen, and how they were expected to govern. Thus, their functions ranged from guaranteeing safety and security, safeguarding jurisdictional sovereignty, land allocation, redistribution of the community's resources to coordinating and supervising socio-economic activities such as farming, hunting, healing, allocating, judging and divining (Busia 1951; Naudascher and Kgatlhanye 1997).

Traditional authorities who abuses their office or failed to perform their functions were impeached through a destoolment process, which was characterized by public ceremonies to indicate the peoples' withdrawal of consent to govern (Busia, 1951; Ayittey, 1991). Prior to contact with Europeans, governance in African societies was based on the principles of centralized and decentralized institutional frameworks. Centralized political systems such as the old Ghana Empire, Mali Empire and Songhai Empire, had institutional bureaucracies for collecting taxes, supervising ceremonies, maintaining law and order, and carrying out the general orders of the traditional leader. The traditional political heads often had subordinates who assisted in the day-to-day administration of their societies. The decentralized systems had no effective bureaucracies; however, their administration was based on kinship. The maintenance of law and order was often deferred to age-set groups, occupational and other groupings. Political power was diffused and shared, and each community was ruled by a council of elders, chosen from different lineages. Unlike the centralized systems, the decentralized systems had no single powerful political authority, and decisions were often made through consensus and compromise at the village assembly and/or council of elders meetings (Ayittey 1991, 1992). Examples of such societies include the Kikuyu of modern Kenya, the Ibo of modern Nigeria and the Nuer of modern Sudan. In between the highly centralized and decentralized societies were groups like the Yoruba of modern Nigeria who had autonomous groups based on lineage with their own chiefs, who also report to a paramount traditional leader or a king (Mumu \& Martin, 2009). 
Under the traditional political arrangements, there were vibrant civil society groups that served as checks on the powers of chiefs and elders and the assemblies of commoners that served as platforms for public consultation and popular participation (Shapera, 1955). Davis (1990: 138) has argued that:

...traditional authority in pre-colonial Nigeria whether in the monarchical, associational or conciliar type was as good, revered and effective as the authority of the kings in Europe and other places that had an organized governmental system. Traditional rulers were in theory and in practice de facto and de jury governors of their domain. They were not dependent on any higher body to exercise their authority. They were not however, absolute rulers as some writers have portrayed them. Rather, their authority and political behavior were limited by institutional restraints, convention and customs.

This form of indigenous independent institutional arrangements existed in many African societies until the last quarter of the nineteenth century when the European colonizers began to systematically construct their colonial states out of and layered on the different societies (Ray, 1998).

Colonial rule in both its direct and indirect forms superimposed structures of governance such as the modern legislature, judiciary, executive, political parties, universal adult suffrage and competitive elections as well as the specific behavioral rules associated with them on existing indigenous traditional political institutions of governance resulting in institutional layering - structural dualism-into the parallel states whose governance institutions are disconnected, with each challenging the legitimacy of the other (Ranger \& Vaughan, 1993). In terms of institutional development, colonialism was a critical juncture in the sense that it signified a moment at which serious exogenous shocks of foreign rule destabilized the existing political institutions in SSA societies thereby opening up possibilities for institutional change.

\section{Bifurcations of States in Africa as Legacies of Institutional Layering}

Against the background of the preceding discussions, it is important to note that institutional destabilization does not necessarily mean institutional destruction. Thus, the type of institutional change that is foisted at critical junctures is dependent on the magnitude and effects of external shocks on existing institutions and the interests as well as the actors associated with them. Because the colonial regime failed to properly acknowledge and adequately address the importance of indigenous political institutions, the development of the modern state as a process of institutional change in SSA societies was one of layering. In other words, the neglect and failure of the colonialists to adequately address the legacies of previously established indigenous institutions has resulted in a fundamental division in modern African states. 
Several scholars, including Ekeh (1975), Ake (1985), Azarya, (1988) and Ihonvbere (1984) have pointed to this division as the major reason why African countries have not been able to achieve the great and optimistic socio-economic transformations anticipated in the years immediately following independence. Ekeh (1975) developed the idea of institutional division in the structure of African states into what he termed "two public realms in postcolonial Africa" - the primordial and the civic publics (p. 96). The primordial public refers to the institutional rules and legacies of indigenous practices, norms and values while the civic public refers to practices, institutions norms, rules and values introduced and left behind by the colonial regime. According to Ekeh (1975), this division is pervasive in every aspect of the postcolonial state. As Adi (2005: 8) noted the core of this argument is that the:

... postcolonial society in Africa is essentially characterized by dualism: the formal and the informal, the modern and the traditional, the rational and the moral, the urban and the rural, the state and the ethnic nation...The conflict between these often opposing forces is the bane of African society and economy. The set of categories captured in formal, modern, rational, and state institutions are colonial importations; whereas the informal, traditional, moral, rural and ethnic-nation categories refer more or less to indigenous African institutions.

Thus, the states that resulted from Africa's encounter with Europe reflected neither what existed in Europe nor the prior indigenous states. Sovereign politics in postcolonial African states is therefore asymmetrically divided between civic state institutions and indigenous institutions; each having their distinct claim to power, sovereignty, legitimacy, and authority (Ray, 1996).

This reality of institutional layering was reproduced over time to restructure the way the politics, economics and social activities were organized in SSA countries. This explains why some scholars argue that using the postcolonial state alone as the central actor for explaining political behavior in SSA countries may not capture important aspects of politics at various levels of the region (Kayea and Beland 2009). Politically, authority is divided between traditional rulers and their council of elders who represent the primordial public on one hand, and elected presidents, legislatures and modern judiciaries, on the other. The politicians of the civic public point to the collective fight for independence, the expression of democratic will through national elections and, the contemporary constitutional and legal systems foisted with the tacit consent of the populace as the sources of legitimacy of political authority associated with the civic public. Chiefs and other traditional rulers on the other hand, trace their legitimacy to pre-colonial institutions and practices, which embody the people's "history, culture, laws and values, religion and even remnants of pre-colonial sovereignty" (Ray \& Reddy, 2003: 5).

While economic activities in the civic public revolve around monetary transactions guided by varied interpretations of capitalist principles, the primordial public is 
associated with the economy of affection (Hyden, 2004, 2006) described in various ways by different scholars as patrimonialism (Bratton \& Van de Walle, 1994), politics of the belly (Bayart, 1993), prebendalism (Joseph, 1987), the moral economy (Adi, 2005) and the instrumentalization of informal politics (Chabal \& Daloz, 1999). Often, transactions in this economy are based on both barter and monetary exchange and group solidarity is prioritized over 'rational' economic principles such as cost benefit analysis and profit motives. Transactions and exchanges in this realm are only economic activities to the extent that the exchange of goods and services occur within it, but it is essentially a relationship of mutuality, reciprocity, solidarity, and group loyalty. As Hyden (2006) has argued, the moral economy operates with a different kind of rationality. Unlike the civic public where conflicts are settled through a retributive justice system, the primordial public uses restorative justice mechanisms embedded in indigenous political institutions to mend broken relationships.

The institutional arrangements for the provision of social services such as health care and old age income support also share this structural dichotomy of institutional layering. In the civic public, the state maintains social protection inherited from the colonial regime for individuals who work in the formal sector. For instance, with the exception of South Africa, Botswana and Mauritius where the national state provides some form of universal or mean-tested benefits such as income support for the aged, all the other SSA countries have established versions of employer-employee contributory social insurance and provident fund pension plans that exclude mostly individuals in the economy of affection from being able to participate. Thus, pre-colonial institutions for social protection established around the extended family and governed by indigenous norms and practices, and theoretically guaranteed by traditional rulers, continue to serve as the major mechanisms for social security in the indigenous public (Kpessa, 2010). The provision of healthcare is divided between modern orthodox medical practices carried out by doctors and nurses trained in western-styled educational institutions in the civic public, and traditional herbalists, soothsayer, spiritualists, and witch-doctors who acquired their skills through inheritance and apprenticeship-the defining educational strategy in the primordial public. Although orthodox health facilities such as clinics, hospitals and laboratories are opened to everyone, pecuniary constraints compel many Africans, especially those in the informal sector to rely on traditional and herbal medicines because medical and health services delivery practices are often embedded in the principles of solidarity and reciprocity.

Institutional layering as a characteristic of African societies in many ways has affected the identity and political behavior of citizens and leaders at all levels. For one thing, citizenship in many African states is highly ambiguous. Many Africans see themselves as subjects of one traditional ruler or the other, and support for traditional authorities such as chiefs, remain very strong in many countries (Crothers, 2003). In countries like Ghana, Nigeria and Botswana among others, almost all the rural and urban jurisdictions regarding land ownership fall under a traditional ruler (Ray \& Reddy, 2003). Thus, while Africans may belong to one civic public or the other exemplified by terms such as Ghanaians, Nigerians, 
Namibians, South Africans, Togolese, Senegalese, Ivorians, Tanzanians and Kenyans, among others, many also strongly identify themselves as citizens of the traditional public and subjects of specific chiefs and kings. This has implications for the formation of the kind of civic identity required for efficiency and stability of the modern state, defined as "a territory in which a single authority exercises sovereign power both de jure (in law) and de facto (in life)" (Watkins, 1968: 150). Because legitimate sovereign authority is divided between the primordial public and the civic public, citizenship is ambiguous and the loyalty of many Africans is divided between the two realms.

If ethnicity is a major issue in African politics, it is because the scale of citizen loyalty and identity between the modern state and the indigenous state system weighs heavily in favor of the latter. As a result, ethnic identity rather than civil society stands at the center of politics in many African countries (Horowits, 2004). What is considered moral and acceptable in the civic realm is often rejected and frowned upon in the indigenous public. In effect, there is competition for the allegiance of the citizenry by the 'two publics' (Ekeh, 1975). This structural dualism highlights the argument that many African states are a combination of political institutions in which formal and informal authorities compete for legitimacy and sovereign authority. Externally, the postcolonial state has all the appearances of a Weberian rational-legal system, with an obvious distinction between public and private spheres, with written laws and constitutional arrangements. Internally, however, it is a layer on equally viable and sturdy indigenous institutions. Thus, rather than path-departing change, indigenous and modern state institutions, exist in parallel to each other as separate layers of a broader political system, and continue to evolve according to their respective institutional logics while shaping each other.

\section{Democratization and Economic Reforms as Institutional Changes}

In the 1980s, several SSA countries embarked on major economic restructuring. This was necessitated by a series of external shocks that hit the continent in the 1970s, bringing a disastrous deterioration in the terms of trade for Africa's largely agrarian economies (Madavo, 2005). Countries in SSA were compelled to privatize public enterprises, eliminate subsidies on social services, liberalize their economies by abolishing market entry regulation, reduce the size of the public sector through retrenchment, introduce competitive foreign exchange regimes, and introduce fee payment for essential services rendered by the state (Aina, Chachage \& Annan-Yao, 2004; Olukoshi, 2000, 2007; Kpessa, 2009). As Adejumobi (2004) has argued, by the early 1990s, there was a shift from state provision of social welfare services towards a market logic. In health, education, and several other social policy areas, policy makers removed state subsidies and introduced user fees.

The logic of rolling back the state, retrenchment of the labour force and the introduction of user fees in schools, hospitals and other institutions that hitherto provided state sponsored social services did not only re-ignite debates about the legitimacy of the 
postcolonial state, it also forced several people into the indigenous public where solidarity and collectivism were the norm thereby enhancing the opportunities structures of traditional institutions. The strong, one-sided anti-state logic that underpinned the implementation of the economic reforms in SSA countries, where state-led social provisioning was the norm in the immediate post-independent years, inevitably took a toll on the capacity of the postcolonial state to deliver social services in recent times (Olukoshi, 2000). This situation has undermined the legitimacy of the state in ways that have compelled citizens to look towards the traditional institutions for social protection. How can a minimalist state withdraw almost completely from economic and social service provisioning and attract popular support or create and sustain an environment for wealth creation when infant industries require some measure of protection from well-established external competitors? The contemporary reality in most SSA countries is that because the state retreated from the provision of health, education and other social services, it can hardly retain the support and legitimacy of its citizens. The result of this is societal withdrawal and heightened ethnic tensions in many African countries.

This problem is further exacerbated by the processes of democratization that followed the implementation of adjustment programs in SSA countries. In many established democracies, political institutions were designed to accommodate important sociocultural variables of individual countries. Following this logic, we would expect that because SSA countries are heavily divided along ethnic and religious lines, their political elites would take into account the socio-cultural diversity of their countries and design institutions that would enhance the legitimacy of the state by ensuring social and political inclusion (Horowits, 2004). On the contrary, about 33 out the 43 SSA countries have adopted American-style presidential systems based on a British winner-takes-all electoral system. In choosing the American model, the contemporary African political elite have neglected the fact that many Africans, especially the rural majority, are first politically socialized within the context of indigenous political institutions and have developed strong bonds and affinities with traditional institutions and norms.

The setback of the winner-takes-all electoral arrangement in structurally divided societies like those in SSA is not only about its zero-sum nature, but also its inherent adversarial premise. In divided societies where the state is expected to keep a delicate balance of cordiality and harmony among different ethnic groups, this type of electoral arrangement cannot achieve that goal. The ethnic conflicts that marked the national election in Kenya, Nigeria, Ivory Coast and Zimbabwe; and the recent return to military rule in Mali, Guinea and Mauritania are few of the many recent examples that illustrate this assertion (Puddington, 2009). The chief of the Bafokeng community in South Africa, his majesty Kgosi Tshekedi Milotlegi (2004), has described Africa's new democracies as "systems that are perfect in theory but flawed in practice" (p. 41) and lamented the failure of SSA political elites to incorporate traditional realities into the design of democratic arrangement of countries on the continent. The adversarial nature of the winner-takes-all or zero-sum electoral politics makes competitive partisan politics exclusionary and highly divisive. Instead of political parties representing class coalitions, they tend to reflect ethno- 
religious affinities and aspiration. In this type of environment, ethnicity is politicized, civic identity is weak, suspicion is high, compromise is low, the potential for consensus is destroyed, genuine electoral defeat is taken as humiliation of one's ethnic group for which there must be violent retaliation, political patronage and corruption become prevalent, and nothing sensible gets done. Taken together, the impact of both structural adjustment, and the pursuit of adversarial liberal democracy have pushed citizens in SSA countries towards building solidarities around indigenous political institutions, and often against the modern state instead of with it (Kpessa, 2011).

As Olukoshi (2000) has noted, in the informal sector where indigenous political institutions wield the most influence is the fastest growing sector on the African continent, serving as it does, as the destination for people laid-off from their jobs and the unemployed. The informal sector has about $70 \%$ of the total population in most SSA countries (Kpessa, 2010), and as Hyden (2006) has argued, although this sector has been originally perceived as a rural phenomenon, it has now expanded to most urban centers on the continent. The deplorable circumstances of health and educational services in most SSA countries, has forced majority of Africans to resort to the use of traditional forms of social service provisioning especially in the area of health care. The social policy vacuum created by the withdrawal of the modern state in the adjustment years has also resulted in the proliferation of traditional herbal healing centers, non-governmental organizations (NGO), faith and community-based educational and health actors, facilities and programs.

While the modern African state continues to undertake various reforms in search of institutional stability, more and more Africans are drifting to their traditional norms and institutions to find meaning for their socio-economic and political existence. Hyden (1990) has argued that in SSA, "while formal structures-both governments and markets-have been collapsing in many countries, the resilience and vibrancy of things African have stood out particularly sharply" (p. 247). In his view, the most distinguishing feature of indigenous African social and political institutions is their malleability - they are often "reoriented and reshaped in response to emerging constraints and opportunities in society" (Hyden, 2006: 183). They persistently reappear to meet new challenges. In the wake of the social disempowerment of the state in Africa, indigenous institutions have regained their voice and are using the democratic decision-making processes as well as direct social services delivery to reassert their legitimacy and authority (Skalnik, 2004).

Institutionalists argue that over time societies "adopt whatever practices they believe their institutional environment deems appropriate or legitimate regardless of whether these practices increase organizational efficiency or otherwise reduce cost relative to benefits" (Campbell, 2004: 18). This is true of current political developments in SSA countries. Since the 1990s, there has been growing scholarly interest in what is seen as the gradual return and influence of traditional political institutions (Ake, 1990; Ayittey, 1991; Davidson, 1992; Buur \& Kyed, 2005, 2007; Ray, 2003; Skalnik, 2004; Ubink, 2008; Davies, 1990; Wunsch \& Oluwu, 1990; Boafo-Arthur, 2001; Agbese, 2004). This interest is informed 
largely by the fact that traditional rulers have been engaged in an institutional conversion through a process of functional transformation through which they incorporate new goals and roles into their old institutional arrangements. Over the last decade, some traditional rulers have directly undertaken projects to provide educational opportunities for individuals from their local jurisdictions as a way of improving the human resource capacity of people within their jurisdiction.

For instance, in the late 1990s, when the government of Ghana under pressure from the International Monetary Fund (IMF) and the World Bank removed subsidies on tertiary education and introduced user fees, students from across the country embarked on demonstrations to protest the policy, arguing that they could not afford the new user fees. Following this educational crisis, Otumfuo Osei Tutu II, the traditional ruler of the Ashanti established an educational endowment fund - the Otumfuo Educational Fund-financed through money obtained from royalties and contributions from Ghanaians at home and abroad to assist academically brilliant but financially poor students obtain higher education (Kpessa, Beland \& Lucour, 2011). By the end of 2004, about 2,000 students had benefitted from scholarships offered by the Otumfuo Educational Fund (Otumfuo Osei Tutu II, 2004).

Similarly, Kgosi Leruo T. Molotlegi, the traditional ruler of the Bafokang in South Africa, has designed an elaborate development program known as Vision 2020 in which human capacity development is a primary goal. He has recruited a team of experts and tasked them to develop strategies for enhancing the role of traditional authorities in supporting students, school, teachers and families with their educational goals. Viewing education as a tool for poverty reduction, health awareness and infrastructure development, the Bafokeng Educational Institute (BEI) was established to offer career development opportunities to citizens and to promote the culture of learning. As others have argued many traditional rulers across the continent have initiated various programs to promote good healthcare practices; and to ensure better social protection in their communities (Economic Commission for Africa, 2007). While many Africa states are still unable to provide services for their people electronically, some indigenous political authorities have modified their operations by taking advantage of modern technology and improvement in communications to directly engage their peoples and the rest of the world. ${ }^{1}$ As Laakso (1996) has argued, by eliminating public expenditure on essential social services such as education and health, economic liberalization has not only increased the distance between modern states and their peoples, it has also created a social policy vacuum which traditional rulers have been smart to fill.

One of the major functions of a strong state is its ability to use its judicial processes to resolve disputes that arise among its people or between any groups of persons and the state. This explains why the judicial arm of government is designed in most countries on the premises of non-partisanship in its operations and appointment of judges. In some SSA countries, the operations of the judicial system have been compromised. As a

See for instance: http://www.bafokeng.com/ 
result, there is growing preference among the general populace for the indigenous courts presided over by traditional rulers. For instance, in Botswana, in 1997, about 80\% of all criminal and civil cases that were settled were handled in the traditional court system (Ubink 2008). Otumfuo Osei Tutu II (2004) has argued that traditional rulers have been most active in dispute resolution in SSA where citizens, disenchanted with the negligent procedures of the formal courts, have demanded traditional methods of conflict resolution. In his view, the suppression of indigenous institutions in some SSA countries, especially in Liberia, Sierra Leone and Cote d'Ivoire was a major contributory factor to the political instabilities witnessed in those countries in the 1990s. The increasing display of preference for the traditional institutions for conflict resolution has attracted the displeasure of some SSA political elites who argue that the traditional leaders are circumventing the rights enshrined in national legal codes and constitutions (Kgosi Leruo Tshekedi Molotlegi, 2004).

In the area of international politics, some traditional rulers have used their influence to bypass the state and directly engage international financial institutions in sourcing funds for the development of their area. For example, Otumfuo Osei Tutu II of the Ashanti of Ghana was successful in obtaining US \$ 4.5 million financial grant from the World Bank under a project codenamed 'partnership' to strengthen the "capacity of chiefs; rehabilitate schools and sanitation facilities in 41 communities, develop health and education modules for traditional authorities to lead in awareness creation on HIV/AIDS; and build programmes designed to preserve traditional values and culture" (Otumfuo Osei Tutu II 2004, p. 36). Similarly, in 2004, the African Economic Commission organized a series of leadership seminars and training workshops for traditional authorities with the purpose of enhancing their institutional capacity (Economic Commission for Africa, 2007). By implication, it is not only the internal sovereignty and legitimacy of the postcolonial state as an institution that is threatened; in fact, its external legitimacy and sovereign authority are also under siege. Englebert (2000) has noted that contemporary traditional rulers of the Buganda Kingdom in Uganda have actively been engaged in international fund-raising activities for development projects. In more recent times, African traditional rulers have also been mobilizing their subjects in the Diaspora for development projects. In doing this, they appoint their own ambassadors to several European and North American cities who act as their spokespersons in various diasporan communities of African origin.

In addition, traditional authorities have also been successful in using the democratic institutions of lobbying, consultation and public participation to gain official recognition in national constitutions and legal frameworks. For instance, in Mozambique, traditional rule which was abolished in the 1970s when the country gained independence, was fully restored again in 2002 (Buur \& Kyed, 2007, 2005), in Uganda, the Kingdom of Buganda which was abolished in the 196os after the King was exiled, was restored in 1995 when the country's Constitution was revised (Herbst, 2000; Englebert, 2000) and in Ghana, the 1992 Constitution recognizes traditional authority and prohibits the postcolonial state from interfering, appointing or refusing to recognize the position of traditional institutions and authorities (Ansah-Koi, 1998; Ray, 2003; Republic of Ghana, 1992; Ubink, 2008; Boafo- 
Arthur, 2001). After the demise of the apartheid regime, South Africa has also passed legislations that both restore traditional institutions to their pre-colonial status, and include them in modern local governance (Republic of South Africa, 2003).

The growing preference for traditional ways of doing things against the modern practices foisted by the colonial era is attested to by various studies conducted by Afrobarometer in 12 SSA countries between 1999 and 2003 on the status of traditional institutions. Overall, these studies have shown that the "popular perceptions of traditional leaders are slightly more positive than those for elected leaders" (Logan, 2008: 1). However, as Hagberg (2007) has argued that the resurgence of traditional institutions has not only blurred the lines between indigeneity and modernity, it has also culminated in situations where some traditional authorities use their closeness or association with politicians to exploit their own people in ways that undermine both rule of law and traditional norms. Hagberg (2007) has also noted the series of instances in Burkina Faso where various traditional authorities have used their proximity to ruling political parties and friendships with high profile politicians to order the execution of citizens without any regard for the laws and traditions.

Beyond this, the growing official recognition and inclusion of traditional political institutions in governance processes in SSA countries is not only a departure from how indigenous institutions were treated in the past, it is also a phenomenon that provides a sense of yet another mechanism of institutional change at work. To be sure, socio-political institutions in SSA countries are being re-configured in ways that combine insights from both indigenous and modern institutional norms, arrangements and practices consistent with what Campbell (2004) described as bricolage. Thus, in the end, effective institutional transformation in Sub-Saharan Africa:

... must take as its point of departure a careful assessment of the way in which country-specific formal and informal political and social institutions shape the incentives of decision makers. For many countries, such an assessment may signal the need to set aside ambitious agendas in favour of more incremental approaches" to institutional change (Levy, 2007: 1).

\section{Conclusion}

This paper has offered a complex understanding of institutional development and change of major political institutions in SSA over time. From the perspective of institutionalists' theory, the general resurgence of traditional political institutions is relevant because it shows that over time, indigenous political institutions have created vested interests that promote the reproduction of their institutional logics in a manner that has been aided by the very strategies designed to foster their discontinuity and path-departing economic and political change in SSA countries. The main lessons here are that because indigenous political institutions, like their modern counterparts create large constituencies and 
are embedded in cultural and customary practices that are based on long-term affinities spanning several generations, they cannot be easily pushed aside. Indigenous African political institutions have proven resilient to various unfavorable conditions foisted largely by colonial and postcolonial governments in the name of modernization (Ubink, 2008; Buur \& Kyed, 2007). Thus, these institutions and the behaviors associated with them, as well as peoples' affinities with them seem locked-in (Thelen 2003, 2004); a particular path of institutional and historical development. They have evolved over time, and persisted in the face of several critical junctures at which new institutions were layered in anticipation of their (i.e., traditional institutions) discontinuity. To this extent, indigenous traditional political institutions are path-dependent especially given that they are still mostly hereditary in succession. However, being path dependent does not mean that traditional political institutions do not experience significant changes. They change along certain dimensions especially through institutional conversion. For instance, they have expanded their goals by adopting important state functions ranging from the provision of modern social services such as education, healthcare and conflict resolution to the recruitment of experts to work in traditional systems, capacity building workshops and the conduct of foreign relations. These processes of institutional conversion have changed traditional political institutions from ones originally based largely on mythology, rituals and secrecy to ones spurred by their visibility, legitimacy and relevance.

Realizing that any attempt to dismantle, radically transform or completely replace the indigenous institutions would be met with resistance from consistencies that depend on them, politicians and policy-makers associated with the institutions of the postcolonial state have resorted to gradually giving traditional institutions formal legal and constitutional recognition in what fits Campbell's (2004) idea of bricolage. Although much more remains to be done, these recognitions go beyond the platitudes of "heritage" and "culture" to embrace the notion that existing socio-political institutions, no matter what we think of them, provide a repertoire of institutional practices and principles that politicians and traditional leaders can collectively use to design institutional solutions. These they do by combining practices, principles, perceptions and ideas from traditional and modern institutions of governance to reconfigure the foundations and structure of the post-colonial state. Contemporary SSA politicians are gradually moving away from the hostile attitudes adopted towards traditional institutions in the years immediately following independence (Ray and Reddy 2003; Ubink 2008). While some SSA countries like Ghana, Uganda, Nigeria and South African, Zambia, Congo, Angola and Mozambique have now formally initiated processes to include traditional institutions in the processes of governance in various ways; others like Lesotho and Swaziland have adopted constitutional monarchies that combine - bricolage-indigenous forms of governance with modern practices of leadership selection.

Finally, beyond creating a dialogue between the literature on socio-economic and political reforms in SSA countries and recent insights in institutionalist theory, this study points to the need to reject the rigid and deterministic view of path-dependence by paying attention to dimensions of overall institutional development and change within as well 
as beyond path-dependence and path-departure (Campbell, 2004). This analysis also shows that pressures emanating from critical junctures do not always result in pathdeparting change; in fact, such pressures and actors' responses to them could re-enforce the resurgence of existing institutional norms in ways that overhaul general institutional development. Overall, institutionalist concepts such as bricolage, layering and conversion provide strong frameworks for analyzing institutional development and change over time. Consequently, future research could explore the relationship between these various mechanisms of institutional change and the specific circumstances under which actors' resort to bricolage, conversion and layering can induce institutional change or re-enforce existing patterns.

\section{References}

Adejumobi, Said (2004). "Economic Globalization, Market Reforms and Social Welfare in West Africa." In T. A. Aina, C. L. Chachage and E. Annan-Yao (eds). Globalization and Social Policy In Africa. Dakar: Council for the Development of Social Science Research in Africa.

Adi, Bongo (2005). "The Moral Economy and the Prospects of Accummulation in SubSaharan Africa: How the IFIs can Help." West Africa Review (7).

Agbese, Pita Ogaba (2004). "Chiefs, Constitutions, and Policies in Nigeria." West Africa Review6.

Aina, Tade Akin, Chachage Seithy Chachage, and Elizebeth Annan-Yao (2004). Globalization and Social Policy in Africa. Dakar, Senegal: Codesria.

Ake, C. (1985). Political Economy of Nigeria. Lagos: Macmillan.

- - (1990). "Sustaining Development on the Indigenous." In The WOerld Bank (ed). Background Papers: The long-Term Perspective Study of sub-Saharan Africa Institutional and Political Issues. Washington, DC: The World Bank.

Ansah-Koi, K. (1998). "Walking a Political Tightrope: Chiefs, Chieftancy and the 1996 General Elections." In Ayee, J. H. (ed). The 1996 General Elections and Democratic Consolidation in Ghana. Accra: Gold-Type Ltd.

Ayittey, G. (1991). Indigenous African Institutions. New York: Transactional Publishers.

- - (1992). Africa Betrayed. USA: Macmillan.

Azarya, V. (1988). The Precarious Balance: State and Society in Africa. Boulder: Westview.

Bayart, J.-F. (1993). The State in Africa: The Politics of the Belly. New York: Longman. 
Baynes, Kenneth (1993). Legitimacy. In J. K. e. al (ed). The Oxford Companion to Politics of the World. Oxford; New York: Oxford University Press.

Beland, Daniel (2007). "Ideas and Institutional Change in Social Security: Conversion, Layering, and Policy Drift." Social Science Quarterly 88 (1):20-38.

Boafo-Arthur, Kwame (2001). “Chieftancy and Politics since 1992." West Africa Review 3 (1).

Bratton, M. , and Nicholas Van de Walle (1994). "Neopatrimonial Regimes and Political Transitions in Africa." World Politics 46 (4).

Busia, Kofi A. (1951). The Position of the Chief in the Modern Political System of Ashanti. London: Oxford University Press.

Buur, Lars, and Helene Maria Kyed (2005). State Recognition of Traditional Authority in Mozambique: The Nexus of Community Representation and State Assistance. Uppsala: Nordiska Afrikainstitutet.

- - (2007). State Recognition and Democratization in Sub-Saharan Africa: $\underline{\text { A New Dawn }}$ for Traditional Authorities? New York: Palgrave, Macmillan.

Campbell, John L. (2004). Institutional Change and Globalization. Princeton \& Oxford: Princeton University Press.

Chabal, P. and P. Daloz (1999). Africa Works: Disorder as Political Instrument. London: James Currey.

Clemens, Elizebeth and James M. Cook (1999). "Politics and Institutionalism: Explaining Durability and Change." Americam Review of Sociology 25:441-66.

Crothers, Charles (2003). "Social Charateristics of Traditional Leaders and Public Views on their Political Role." In Ray, D. \& Reddy, P. S. (eds). Grassroots Governance? Chiefs in Africa and the Afro-Caribbean. Calgary, Alberta: University of Calgary Press.

Davidson, B. (1992). The Black Man's Burden: Africa and the Curse of the Nation-State. New York: Times Books.

Davies, A. E. (1990). “The Fluctuating Fortunes of Traditional Rulers in Nigeria.” Journal of Plural Societies XIX (2).

Economic Commission for Africa. (2007). Harnessing Traditional Governance in Southern Africa. Ethiopia, Addis Ababa: Economic Commission for Africa.

- - (2007). Relevance of African Traditional Institutions of Governance. Ethiopia, Addis Ababa: Economic Commission for Africa. 
Ekeh, P. (1975). “Colonialism and the Two Publics: A Theoretical Statement." Comparative Studies in Society and History 17 (1):91-112.

Englebert, P. (2000). "Patterns and Theories of Traditional Resugence in Tropical Africa." Mondes en Development 30 (118):51-64.

- - - (2000). "Pre-Colonial Institutions, Post-Colonial States, and Economic." Political Research Quarterly53 (7).

Hacker, Jacob (2004). "Privatizing Risk without Privatizing the Welfare State: The Hidden Politics of Social Policy Retrenchment in the United States." America Political Science Review 98 (2):243-259.

Hagberg, Stan (2007). "Traditional Chieftancy, Party Politics, and Political Violence in Burkina Faso." In Buur, L. \& Kyed, H. M. (eds). State Recognition in Sub-Saharan Africa: A New Down for Traditional Authorities? New York: Palgrave Macmillan.

Herbst, J. (2000). States and Power in Africa: Comparative Lessons in Authority and Control. Princeton, NJ: Princeton University Press.

Horowits, Donald L. (2004). "Some Realism about Constitutional Re-engineering." In Wimmer, Andreas, R.J. Gladstone, D. L. Horowits \& C. Schrtter (eds). Facing Ethnic Conflicts: Towards A New Realism, Lamhan, Boulder, NY, Toronto, \& Oxford: Rowman and Littlefield Publishers, Inc.

Hyden, Goran 1(990). "Reciprocity and Governance in Africa." In Wunsch, J.S. \& Oluwu, D. (eds). The Failure of Centralized State: Institutions and Self-Governance in Africa, Boulder, San Francisco \& Oxford: Westview Press.

- - (2004). "Informal Institutions, the Economy of Affection, and Rural Development in Africa." Tanzania Journal of Population Studies and Development 11 (2):1-20.

- - (2006). African Politics In Comaparative Perspective. Cambridge: Cambridge University Press.

Ihonvbere, J. 1(984). “The Irrelevant State, Ethnicity and the Quest for Nationhood in Africa." Ethnic and Racial Studies 17.

Joseph, R. (1987). Democracy and Prependal Politics in Nigeria: The Rise and Fall of the Second Republic. Cambridge: Cambridge University Press.

Kayea, Julie, and Daniel Beland (2009). "The Politics of Ethnicity and Post-Conflict Reconstruction: The Case of Northern Ghana." Journal of Contemporary African Studies 27 (2):177-200.

Kgosi Leruo Tshekedi Molotlegi (2004). "Traditional Leadership for Progressing Africa." A Paper Presented at Fourth African Development Forum \& United Nations 
Economic Commission for Africa. Ethiopia, Addis Ababa: Economic Commission for Africa.

Khapoya, Vincent B. (1994). The African Experience: An Introduction. Englewood Cliffs, New Jersey: Princeton Hall.

Kingdon, John W. (1995). Agendas, Alternatives, and Public Policies. New York: Harper Collins.

Kpessa, Michael (2009). “Africa's NEPAD Vision: Ambiguities, Contradictions and Crisis of Internalizing External Models of Development.” In Huque, A. S. (ed). The Enigma of Development. New Delhi, India: South Asia Publishers PVT LTD.

- - (2010). "Ideas, Institutions and Welfare Program Typologies: An Analysis of Pensions and Old Age Income Protection Policies in Sub-Saharan Africa." Poverty and Public Policy 2 (1):Article 4.

Laakso, Lisa (1996). "The Changing Notions of the Nation-State and the African Experience: Montesquieu Revisited." In Olukoshi, O. A. (ed). Challenges to the Nation-State in Africa.. Uppsala: Nordic Africa Institute.

Levy, Brian (2007). "State Capacity, Accountability and Economic Development." Commonwealth and Comparative Politics 45 (2):499-520.

Logan, Carolyn (2008). "Traditional Leaders in Modern Africa: Can Democracy and the Chief Co-exist?" Cape Town: Afro Baromter.

Madavo, Callisto (2005). "Africa: The Development Challenges of the 21st Century." Africa Program Occasional Paper Series. Washington DC: Woodrow Wilson International Center for Scholars.

Mahoney, James (2000). "Path Dependence in Historical Sociology." Theory and Society 29 (4):507-48.

- - - (2001). "Path Dependent Explanations of Regime Change." Studies in Comparative International Development 36 (1).

- - - (2006). "Path Dependence: Lessons from the Social Sciences." In Wimmer, A. \& Kossler, R. (eds). Understanding Change, Models, Methodologies and Metaphors. Basingstoke: Palgrave MacMillian.

Mumu, Wa Mueni and Guy Martin. (2009). A New Paradigm of the African State. USA: Palgrave MacMillan.

Naudascher, K , and N Kgatlhanye. (1997). "Report of the Regional Conference on Traditional Leadership." South Africa: Friedrich Ebert Stiftung. 
Olukoshi, Adebayo. (2000). "Structural Adjustment and Social Policies in Africa: Some Notes.” GASPP 4: Seminar on Global Social Policies and Social Rights. New Delhi, India: The Nordic Africa Institute.

——— (2007). “Africa: Bringing the Social Back In.” Global Social Policy 7 (95):95-103.

Otumfuo Osei Tutu II. (2004). "Traditional Systems of Governance and the Modern State.” A Paper Presented at the Fourth African Development Forum \& United Nations Economic Commission for Africa. Addis Ababa: Economic Commission for Africa.

Pierson, Paul. (1993). "When Effects Become Cause: Policy Feedback and Political Change." World Politics 45:595-628.

- - - (1994). Dismantling the Welfare State? Reagan, Thatcher, and the Politics of Retrenchment. Cambridge: Cambridge University Press.

_-_- (1996). “The New Politics of Welfare State.” World Politics 48.

- _- (1998). "Irresistible Forces, Immoveable Objects: Post-Industrial Welfare State Confront Permanent Austerity." European Public Policy 5 (4):539-56o.

- - (2000). "Increasing Returns, Path Depedence, and the Study of Politics." America Political Science Review 251-66.

- - (2000). "Not Just When, but What: Timing and Sequence in Political Processes." Studies in American Political Development 14:72-92.

- - (2004). Politics in Time: History, Institutions and Social Analysis. Princeton. NJ: Princeton University Press.

Puddington, Arch. (2009). “Another Year of Decline: A Third Year of Decline.” Journal of Democracy Volume 20, Number 2 April 200920 (2):93-107.

Ranger, Terence, and Olufemi Vaughan. (1993). Legitimacy and the state in Twentieth Century Africa. London: Macmillan.

Ray, D. (1996). “Divided Sovereignty: Traditional Authority and the State in Ghana." Legal Pluralism and Unofficial Law 37 \& 38:181-202.

- - - (1998). "Chief-State Relations in Ghana-Divided Sovereignty and Legitimacy." In Nieuwaal, E.A. v. R. v. \& W. Zips (eds). Sovereignty, Legitimacy and Power in West African Societies. New Bruswick (USA); London (UK): Transactional Publishers.

Ray, Donald. (2003). "Ghana: Traditional Leadership and Rural Local Governance." In Ray, D. \& P.S. Reddy (eds). Grassroots Governance? Chiefs in Africa and the AfroCaribbean. Calgary, Alberta: University of Calgary Press. 
Republic of Ghana. (1992). The Constitution of Ghana. Accra: Government of Ghana.

Republic of South Africa. (2003). "Traditional Leadership and Governance Framework Bill.” In MoPaL (ed). Government: Government of South Africa. Johannesburg, South Africa: Republic of South Africa

Shapera, I.A. (1955). Handbook of Tswana Law and Customs. London Oxford University Press.

Skalnik, P. (2004). "A Universal Political Formation." Focaal-European Journal of Anthropology 43:76-98.

Thelen, Kathleen. (2003). "How Institutions Evolve: Insights from Comparative Historical Analysis.” In Mahoney, J. \& Rueschemeyer, D. (eds). Comparative Historical Analysis in the Social Sciences. Cambridge: Cambridge University Press.

- - (2004). How Institutions Evolve: The Political Economy of Skills in Germany, Britain, United States and Japan. Cambridge: Cambridge University Press.

Ubink, Janine. (2008). In the Land of the Chiefs: Customary Law, Land Conflicts, and the Role of the State in Peri-Urban Ghana. Armsterdam: Leiden University Press.

- - - (2008). Traditional Authorities in Africa: Resurgence in an Era of Democratization: Research \& Policy Note. Leiden: Leiden University Press.

Watkins, Fredrick M. (1968). “'State' The Concept.” In Sills, D. L. (ed). International Encyclopedia of Social Sciences.

Weyland, Kurt (2008). “Towards a New Theory of Institutional Change.” World Politics 60:281-314.

Wunsch, James S., and Dele Oluwu (1990). The Failure of the Centralized State: Institutions and Self-Governance in Africa. Boulder, San Francisco \& Oxford. 